Jurnal Kimia Sains dan Aplikasi 25 (1) (2022):7-12
ISSN: 1410-8917
Jurnal Kimia
Aplikasi

\title{
Facile synthesis of 5-Isopropyl-2,3-dimethylbenzene-1,4-diol by Friedel-Crafts and Determination of Partition Coefficient in
} $n$ - Octanol/Water

\author{
Siti Mariyah Ulfa ${ }^{\mathrm{a}, \mathrm{b},{ }^{*},}$, Alma Miranda a ${ }^{\text {a }}$ Fath Dwisari ${ }^{\mathrm{a}}$, Mohammad Farid Rahman $^{\mathrm{a}, \mathrm{b}}$ \\ ${ }^{a}$ Chemistry Department, Faculty of Science, Brawijaya University, Jl. Veteran Malang, Malang, Indonesia \\ ${ }^{\mathrm{b}}$ Synthesis and Catalysis of Natural Product Research Group, Faculty of Science, Brawijaya University, Jl. Veteran, Malang, Indonesia
}

*Corresponding author: ulfa.ms@ub.ac.id

https://doi.org/10.14710/jksa.25.1.7-12

\begin{tabular}{|c|c|}
\hline Article Info & Abstract \\
\hline $\begin{array}{l}\text { Article history: } \\
\text { Received: } 11^{\text {th }} \text { November } 2021 \\
\text { Revised: } 22^{\text {nd }} \text { January } 2022 \\
\text { Accepted: } 24^{\text {th }} \text { January } 2022 \\
\text { Online: } 31^{\text {st }} \text { January } 2022 \\
\text { Keywords: } \\
\text { alkylation reaction; Brønsted } \\
\text { acid; hydroquinone; isopropyl } \\
\text { alcohol; partition coefficient }\end{array}$ & $\begin{array}{l}\text { The wide therapeutic effect of quinone-based drugs has received considerable } \\
\text { interest for a long time. In this research, Friedel-Crafts performed a facile } \\
\text { synthesis of quinone derivatives using the mixture of Brønsted acid. Reflux of } 2,3 \text { - } \\
\text { dimethylhydroquinone (1), isopropanol, glacial acetic acid, and } \mathrm{H}_{2} \mathrm{SO}_{4} \text { for } 15 \\
\text { minutes gave yellow oil product of } 5 \text {-isopropyl-2,3-dimethylbenzene-1,4-diol } \\
\text { (2) as a major product. Characterization using Nuclear Magnetic Resonance } \\
\text { (NMR) revealed the methine proton splitting for isopropyl at } \delta 3.13 \mathrm{ppm} \text {, which } \\
\text { has a cross-coupling with aromatic carbon at } \delta 119.6 \mathrm{ppm} \text { suggested the } \\
\text { substitution of a proton on quinone ring with isopropyl group. Analysis Fourier } \\
\text { Transform Infra-Red (FT-IR) showed the broad spectrum of -OH, the vibration } \\
\text { of CH sp3, and isopropyl groups. The minor products identified as } 5 \text {-isopropyl- } \\
2,3 \text {-dimethylcyclohexa-2,5-diene-1,4-dione (3), 5-isopropyl-2,3-dimethyl-1,4 } \\
\text { phenylene diacetate }(4) \text {, and } 2,3 \text {-dimethylbenzene-5,6-isopropyl-1,4-diol }(5) \\
\text { confirmed from } 2 \mathrm{D} \text { HETCOR and MS analysis. The partition coefficient (log } P \text { ) of } \\
\text { compound } 2 \text { showed a higher solubility by } 1.9 \text {-fold compared to hydroquinone } 1 \text {. } \\
\text { It is suggested that an additional methyl group increased the partition into the } \\
\text { organic phase. }\end{array}$ \\
\hline
\end{tabular}

\section{Introduction}

Over the years, the therapeutic effect of black seed Nigella sative to exert antitumor, antioxidant, anticancer, and anti-inflammatory have been reported [1, 2, 3, 4]. Thymoquinone (TQ 2-isopropyl-5-methyl-1,4benzoquinone) and thymohydroquinone (THQ 5isopropyl-2-methylbenzene-1,4-diol) are two main bioactive compounds found in the essential oil of the black seed. TQ and THQ have a quinone framework, reported as the principal skeleton for its pharmaceutical activity [5]. TQ research is leading because it exhibits selective cytotoxic against many cancer cell types without affecting the normal cells $[6,7]$. Some studies on THQ for antitumor agents recently revealed that it works similarly to TQ [8]. Thus, the development of THQ for prospective drug candidates has become an exciting research area.
Account to synthesis TQ has been reported. Synthesis of cationic plastoquinone possesses potent antioxidant activity by using phenyl phosphonium ion channels, increasing the penetrating ability into membranes, mitochondria, cells, and organisms (Fig. 1) [9]. The insertion of bromoalkyl substituent in benzoquinone derivatives, such as in 3-(10-bromodecyl)-5-isopropyl2-methyl-1,4-benzoquinone [10], 5-(7-bromoheptyl)2,3- dimethyl-1,4- benzoquinone and 5- (10- bromodec yl)-2,3-dimethyl-1,4- benzoquinone [11], 2- (5- brom oamyl)-3,5-dimethyl-1,4-benzoquinone and 2-(5bromoamyl)-5-methyl-1,4-benzoquinone have been reported to increase the solubility of the compounds in noctanol/water system. The presence of alkyl substituents also demonstrated the increasing cytotoxicity against human cancer cell lines and mouse macrophage cell lines [12]. 


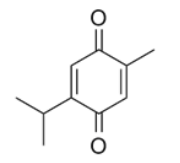

Thymoquinone (TQ)

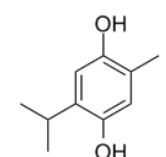

Thymohydroquinone (THQ)
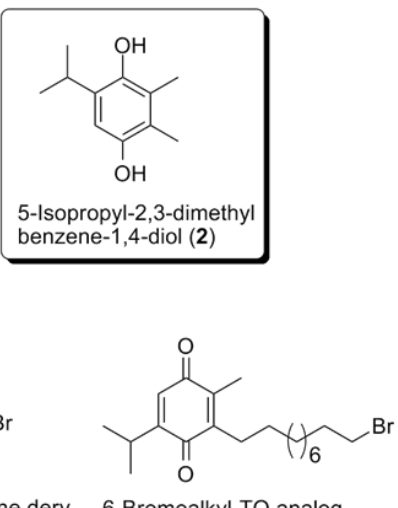

Cationic plastoquinone derv.
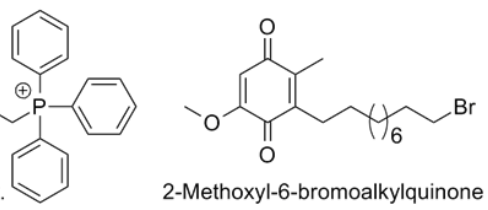

2-Methoxyl-6-bromoalkylquinone derv. 6-Bromoalkyl-TQ analog

Figure 1. Examples of the reported quinone-based compounds

Due to the overall therapeutic effect of quinone derivatives, this research proposes the synthesis of 5isopropyl-2,3-dimethylbenzene-1,4-diol (2) (Scheme 1). The synthesis of compound 2 was carried out by FriedelCrafts using a mixture of Brønsted acid, $\mathrm{H}_{2} \mathrm{SO}_{4}$, and acetic acid. Isopropanol is used as an electrophile to generate isopropyl carbocation [13]. Compound 2 is fascinating; it has two hydroxyl groups engaged in the hydrogen bonds and the isopropyl or dimethyl groups increasing the hydrophobic contacts with nonpolar residues inside the binding site [14]. Because hydrophobicity is a general property that controls the distribution of compounds between membrane lipid and aqueous phase. The partition coefficients and the steric fits to its natural binding sites can significantly affect [15]. In this regard, each compound's biological function and activity might be different.

Herein, we reported the synthesis of 5-isopropyl2,3-dimethylbenzene-1,4-diol (2) by modified FriedelCrafts. The synthesized compound differs from TQ in the number of methyl substituents and hydroxyl groups, making it possible to tailor the hydrophobic-hydrophilic balance to penetrate the cell membrane.

\section{Methodology}

\subsection{Materials and Instrumentation}

2,3-Dimethylhydroquinone $\left(\mathrm{C}_{8} \mathrm{H}_{10} \mathrm{O}_{2}\right)$ and sulfuric acid $\left(\mathrm{H}_{2} \mathrm{SO}_{4}\right.$ 98\%) were obtained from Sigma Aldrich, Singapore, and used as received. Isopropanol $\left(\mathrm{C}_{3} \mathrm{H}_{7} \mathrm{OH}\right)$ and glacial acetic acid $\left(\mathrm{CH}_{3} \mathrm{COOH}\right)$ were received from Merck, Singapore. N-hexane, ethyl acetate, chloroform, and methanol for column chromatography were obtained in technical grade from the Malang vendor and distilled before use. The solvent for the solubility test, $n$-octanol (organic phase), and phosphate buffer (water phase) were prepared freshly before the experiment.

The FTIR spectrum was measured using Shimadzu $8400 \mathrm{~S}$ with $\mathrm{NaCl}$ salt plate. The UV-Visible was measured using spectrophotometer UV-Visible Shimadzu $1600 .{ }^{1} \mathrm{H}-$ NMR and ${ }^{13} \mathrm{C}-\mathrm{NMR}$ were recorded using JEOL ECS400 with TMS as internal standard ( $\delta 0.00 \mathrm{ppm})$ and $\mathrm{CDCl}_{3}$ as a solvent ( ${ }^{1} \mathrm{H}-\mathrm{NMR}, \delta 7.26 \mathrm{ppm}$, singlet; ${ }^{13 \mathrm{C}-\mathrm{NMR}, \delta} 77.04$ ppm, triplet). High-Performance Liquid Chromatography (HPLC) Shimadzu LC-20AD Prominence connected with COSMOSIL packed column 5C18-MS-II 10ID x $250 \mathrm{~mm}$ and FID detector used for purification of the product.

\subsection{Experiment}

\subsubsection{Friedel-Crafts reaction of 2,3-dimethylhydroquinone}

The Friedel-Crafts reaction performed based on reported method [16]. The reaction temperature modified to optimize the product yield. 2,3-Dimethylhydroquinone (1) $(7.3 \mathrm{mmol} ; 1 \mathrm{~g})$, isopropanol (21.2 mmol; 1,6 mL), and glacial acetic acid $(52.4 \mathrm{mmol} ; 3 \mathrm{~mL})$ put in the threeneck round bottom flask and stirred until all the solid reagent dissolved. Put the flask on the ice bath then slowly added $4 \mathrm{~mL}$ cold $\mathrm{H}_{2} \mathrm{SO}_{4} 98 \%$ and stirred slowly. Continued stirred until the solution reach to room temperature. After that, refluxed the solution at $55-60^{\circ} \mathrm{C}$ for 15 minutes, remove from water bath and pour into ice cube, added with water, and slowly stirred to get dark brown precipitate. Filtered the precipitate using Buchner funnel, dried in the oven at $120^{\circ} \mathrm{C}$ for a night. The crude product as black solid collected in $760 \mathrm{mg}$, and then subjected into $\mathrm{SiO}_{2}$ column chromatography using $n$-hexane $(100 \%)$ as an eluent. The major compound collected from fraction 3 as yellow oil (371 mg; $52.3 \%$ ).

TLC analysis using $n$-hexane/ethyl acetate (9:1) gave $\mathrm{Rf}=0.28$; UV-Vis analysis showed the $\mathrm{l}_{\max } 256 \mathrm{~nm}$. The FTIR analysis revealed the bending of $\mathrm{CH}_{3}$ at 1468 and $1378 \mathrm{~cm}^{-1}$, has a splitting with the same intensity characteristic for isopropyl absorption. The NMR analysis of products is as follows: 5-Isopropyl-2,3dimethylbenzene-1,4-diol (2): ${ }^{1} \mathrm{H}-\mathrm{NMR}$ (400 $\mathrm{MHz}$, $\left.\mathrm{CDCl}_{3}\right) \delta 6.95(\mathrm{~s}, 1 \mathrm{H}, \mathrm{H}-6), 4.63$ (s, $\left.2 \mathrm{H}, \mathrm{OH}\right), 3.13$ (sext., $1 \mathrm{H}$, $J=6.8 \mathrm{~Hz}, \mathrm{H}-9), 2.03(\mathrm{~s}, 3 \mathrm{H}, \mathrm{H}-7), 2.01(\mathrm{~s}, 3 \mathrm{H}, \mathrm{H}-8), 1.20$ $(\mathrm{d}, 6 \mathrm{H}, \mathrm{J}=6.8 \mathrm{~Hz}, \mathrm{H}-10 ; \mathrm{H}-11) ;{ }^{13} \mathrm{C}-\mathrm{NMR}\left(100 \mathrm{MHz}, \mathrm{CDCl}_{3}\right)$

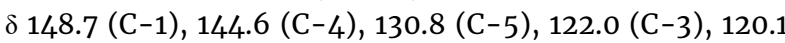
(C-2), 119.6 (C-6), 27.8 (C-9), 23.8 (C-10; C-11), 12.6 (C7), 12.5 (C-8). 5-Isopropyl-2,3-dimethylcyclohexa-2,5diene-1,4-dione (3): ${ }^{1} \mathrm{H}-\mathrm{NMR}\left(400 \mathrm{MHz}, \mathrm{CDCl}_{3}\right) \delta 6.47$ (s, $1 \mathrm{H}, \mathrm{H}-6$ ), 3.04 (sext., $1 \mathrm{H}, J=6.8 \mathrm{~Hz}, \mathrm{H}-9$ ), 2.05 (s, 6H, H7; H-8), 1.10 (d, 6H, J = 6.8 Hz, H-10, H-11); ${ }^{13} \mathrm{C}-\mathrm{NMR}(100$ $\left.\mathrm{MHz}, \mathrm{CDCl}_{3}\right) \delta 188.2(\mathrm{C}-1), 187.3(\mathrm{C}-4), 154.6(\mathrm{C}-5), 141.3$ (C-2), 140.1 (C-3), 130.1 (C-6), 27.2 (C-9), 21.6 (C-10, C11), 13.6 (C-7; C-8). 5-Isopropyl-2,3-dimethyl-1,4phenylene diacetate (4): ${ }^{1} \mathrm{H}-\mathrm{NMR}\left(400 \mathrm{MHz}, \mathrm{CDCl}_{3}\right) \delta 7.03$ (s, $1 \mathrm{H}, \mathrm{H}-6$ ), 2.90 (sext., $1 \mathrm{H}, J=6.8 \mathrm{~Hz}, \mathrm{H}-9), 2.34$ (s, 6H, H-2"), 2.04 (s, 6H, H-7; H-8), 1.09 (d, 6H, J = 6.8 Hz, H10; $\mathrm{H}-11$ ); ${ }^{13} \mathrm{C}-\mathrm{NMR}\left(100 \mathrm{MHz}, \mathrm{CDCl}_{3}\right) \mathrm{d} 169.8$ (C-1'; C=O), 148.8 (C-1), 144.3 (C-4), 140.1 (C-5), 132.3 (C-3), 128.2 (C- 
2), $120.1(\mathrm{C}-6), 28.2$ (C-9), 21.9 (C-2"), 21.6 (C-10, C-11), $12.9(\mathrm{C}-7 ; \mathrm{C}-8)$.

\subsubsection{Determination of partition coefficients $(\log P)$ in n-octanol/water system}

Determination of partition coefficient $(\log P)$ carried out by shake-flask methods using aqueous phases buffered phosphate ( $\mathrm{pH} 7.4$ ) and saturated $n$-octanol according to the published procedure $[17,18]$. Ten $\mathrm{mM}$ of compound 2 dissolved in saturated $n$-octanol. Partition of $n$-octanol/water prepared in the ratio of 3:7 $(\mathrm{v} / \mathrm{v})$. The partition system is shaken using an orbital shaker for one hour at room temperature. After equilibrium, both the $n$ octanol and aqueous phase were injected into HPLC eluted with acetonitrile/water (70:30) in 3\% acetate acid. $\log P$ calculated according to equation 1 :

$$
\log P=\log \frac{C_{\text {octanol }}}{C_{\text {water }}}=\log \frac{A_{o} / V_{o}}{A_{w} / V_{w}}
$$

C stands for the compound's concentration, A the area of the compound under the spectrum curve, $\mathrm{V}$ the volume of the phase, and subscripts, $w$ and o refer to the water phase and organic phase ( $n$-octanol phase).

\section{Results and Discussion}

\subsection{Friedel-Crafts reaction of}

2,3-dimethylhydroquinone

The synthetic pathways to obtain THQ derivatives compound 2-5 is described in Scheme 1. The mixed acid, $\mathrm{H}_{2} \mathrm{SO}_{4}$, and $\mathrm{CH}_{3} \mathrm{COOH}$ act as a protic acid catalyst and isopropanol act as a nucleophile which is protonated by acid and eliminate $\mathrm{H}_{2} \mathrm{O}$ to give isopropyl carbocation. Since the intermediate cation is stable and does not undergo rearrangement, it becomes an excellent electrophile to initiate Friedel-Crafts reaction [13].
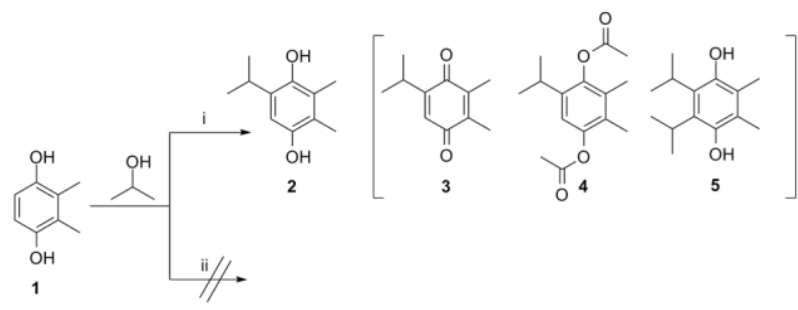

Scheme 1. Reagents and reaction conditions: (i) $\mathrm{CH}_{3} \mathrm{COOH}, \mathrm{H}_{2} \mathrm{SO}_{4} 98 \%, 55-60^{\circ} \mathrm{C}, 15 \mathrm{~min}$; (ii) $\mathrm{H}_{2} \mathrm{SO}_{4} 98 \%$, $55-60^{\circ} \mathrm{C}, 15 \mathrm{~min}$

TLC analysis of crude product gave three spots; Rf1 0.05 , Rf2 0.15 , and Rf3 0.28 eluted using $100 \% \mathrm{n}$-hexane. The spot in origin is confirmed as unreacted starting material 2,3-dimethylhydroquinone (1). Separation using $\mathrm{SiO} 2$ column chromatography collected fraction 3 as the primary isolated product (370.96 $\mathrm{mg} ; 52.3 \%$ ). Even fraction 3 has one spot in the TLC plate. Further analysis using HPLC detected four individual peaks (Fig. 2). It is predicted that four compounds consist in fraction 3 . Further separation using HPLC was carried out using isocratic eluent $\mathrm{MeOH} / \mathrm{ACN}(90: 10 \mathrm{v} / \mathrm{v})$ to give four compounds 2-5.

The NMR data show in Table 1. Proton and carbon NMR of compounds $2-4$ are quite similar. By combining the Mass Spectra (MS) and NMR data analysis, the structure determination of $2-4$ is proposed. Due to the similarity of the quinone skeleton, only compound 2 was discussed in detail. The analogous structure of compounds 3 and 4 is derived based on compound 2 .

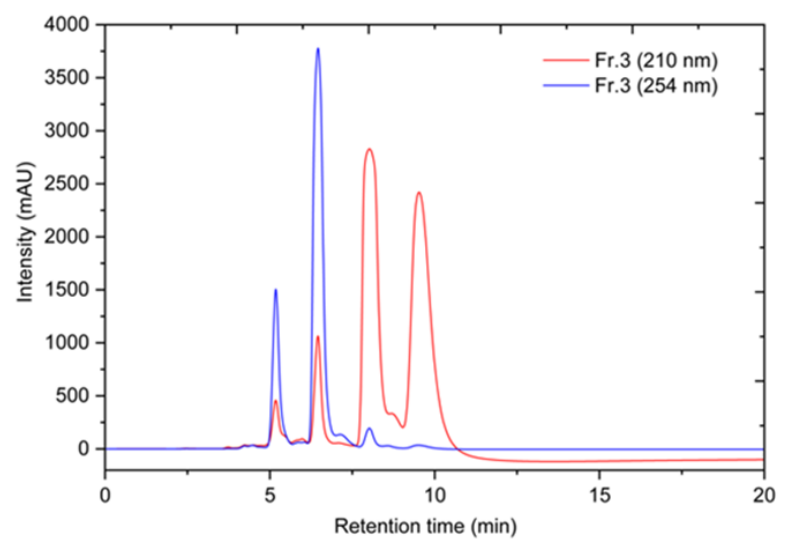

Figure 2. The HPLC spectrum of fraction 3 consists of four peaks analyzed at $210 \mathrm{~nm}$ and $254 \mathrm{~nm}$, suggesting four compounds

Table 1. NMR data for compounds 2, 3, and 4

\begin{tabular}{|c|c|c|c|}
\hline Comp. & Position & $\mathrm{d}_{\mathrm{c}}$, type & $\mathrm{d}_{\mathrm{H}}(\mathrm{J}$ in $\mathrm{Hz})$ \\
\hline \multirow{12}{*}{2} & 1 & 148.7 & - \\
\hline & 2 & 120.1 & - \\
\hline & 3 & 122.0 & - \\
\hline & 4 & 144.6 & - \\
\hline & 5 & 130.8 & - \\
\hline & 6 & 119.6 & $6.95(\mathrm{~s}, 1 \mathrm{H})$ \\
\hline & 7 & 12.6 & $2.03(\mathrm{~s}, 3 \mathrm{H})$ \\
\hline & 8 & 12.5 & $2.01(\mathrm{~s}, 3 \mathrm{H})$ \\
\hline & 9 & 27.8 & 3.13 (sext., $1 \mathrm{H}, J=6.8$ ) \\
\hline & $10-11$ & 23.8 & $1.20(\mathrm{~d}, 6 \mathrm{H}, J=6.8)$ \\
\hline & $1^{\prime}(-\mathrm{OH})$ & - & $4.63(\mathrm{~s}, 2 \mathrm{H})$ \\
\hline & 4' $(-\mathrm{OH})$ & - & - \\
\hline \multirow{10}{*}{3} & 1 & 188.2 & - \\
\hline & 2 & 141.3 & - \\
\hline & 3 & 140.1 & - \\
\hline & 4 & 187.3 & - \\
\hline & 5 & 154.6 & \\
\hline & 6 & 130.1 & $6.47(\mathrm{~s}, 1 \mathrm{H})$ \\
\hline & 7 & 13.6 & $2.05(\mathrm{~s}, 3 \mathrm{H})$ \\
\hline & 8 & 13.6 & $2.05(\mathrm{~s}, 3 \mathrm{H})$ \\
\hline & 9 & 27.2 & 3.04 (sext., $1 \mathrm{H}, J=6.8)$ \\
\hline & $10-11$ & 21.6 & $1.10(\mathrm{~d}, 1 \mathrm{H}, J=6.8)$ \\
\hline \multirow{12}{*}{4} & 1 & 148.8 & - \\
\hline & 2 & 128.2 & - \\
\hline & 3 & 132.3 & - \\
\hline & 4 & 144.3 & - \\
\hline & 5 & 140.1 & - \\
\hline & 6 & 120.1 & $7.03(\mathrm{~s}, 1 \mathrm{H})$ \\
\hline & 7 & 12.9 & $2.04(\mathrm{~s}, 3 \mathrm{H})$ \\
\hline & 8 & 12.9 & $2.04(\mathrm{~s}, 3 \mathrm{H})$ \\
\hline & 9 & 28.2 & $2.90($ sext. $, 1 \mathrm{H}, J=6.8)$ \\
\hline & $10-11$ & 21.6 & $1.09(\mathrm{~d}, 1 \mathrm{H}, J=6.8)$ \\
\hline & $1^{\prime}(\mathrm{C}=\mathrm{O})$ & 169.8 & - \\
\hline & $2 "$ & 21.9 & $2.34(\mathrm{~s}, 6 \mathrm{H})$ \\
\hline
\end{tabular}


The chemical shift analysis of compound 2 is defined at $6.95 \mathrm{ppm}(\mathrm{s}, 1 \mathrm{H})$ for aromatic proton and $3.13 \mathrm{ppm}$ (sext., $1 \mathrm{H}, J=6.8 \mathrm{~Hz}$ ) for methine proton in isopropyl framework $\mathrm{CH}_{3}-\mathrm{CH}-\mathrm{CH}_{3}$ [19]. The other proton was observed at $1.27 \mathrm{ppm}(\mathrm{d}, 6 \mathrm{H}, \mathrm{J}=6.8 \mathrm{~Hz})$ for an equivalent methyl proton directly attached to isopropyl $\mathrm{CH}_{3}-\mathrm{CH}-$ $\mathrm{CH}_{3}$. HMBC correlation from $\mathrm{H}-9$ ( $\left.\delta 3.13\right)$ to $\mathrm{C}-4$ ( $\left.\delta 144.6\right)$, $C-5$ ( $\delta 130.8)$, and $C-6$ ( $\delta 119.6)$ suggested that isopropyl attached at $\mathrm{C}-5$. Furthermore, HMBC cross-coupling showed the correlation of $\mathrm{H}-8(\delta 2.01)$ with $\mathrm{C}-1$ ( $\delta$ 148.7) and $\mathrm{C}-3$ ( $\delta$ 122.0); $\mathrm{H}-7$ ( $\delta 2.03)$ with $\mathrm{C}-2(\delta 120.1)$ and $\mathrm{C}-4$ ( $\delta$ 144.6), then situated the dimethyl substituent at $\mathrm{C}-2$ and $\mathrm{C}-3$, respectively. The presence of $\mathrm{OH}$ is considered from the singlet peak at $\delta 4.36 \mathrm{ppm}$, which shifted into $\delta$ 4.76 ppm by $\mathrm{D}_{2} \mathrm{O}$ exchange NMR. Furthermore, FTIR analysis confirmed the broad spectrum at 3613-3275 $\mathrm{cm}^{-1}$. Thus, the structure determination of compound 2 is depicted in Fig. 3.
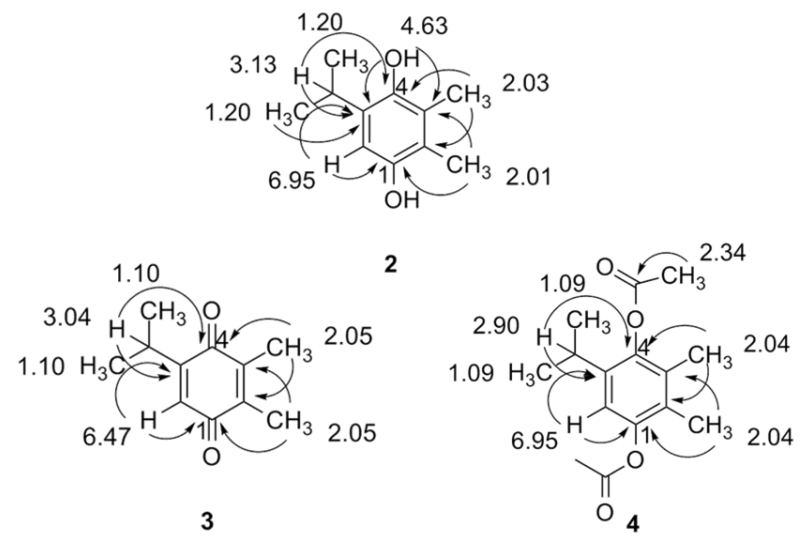

Figure 3. Structure of compounds 2, 3, and 4

Analysis of compound 3 predicted the presence of aromatic carbonyl $(\mathrm{C}=\mathrm{O})$ from the quinone skeleton at 187.3 and 188.3 ppm. Proton at $\mathrm{C}-3$ is shifted to a lower chemical shift $6.47 \mathrm{ppm}(\mathrm{s}, 1 \mathrm{H})$ due to the shielding effect of carbonyl groups. HMBC analysis showed the crosscoupling of $\mathrm{H}-9$ ( $\delta 3.04)$ to $\mathrm{C}-4(\delta 187.3), \mathrm{C}-5$ ( $\delta 154.6)$, and C-6 ( $\delta$ 130.1). The sharp peak of aromatic carbonyl from FTIR analysis was detected at $1649 \mathrm{~cm}^{-1}$. Compound 4 based on FTIR spectrum showed the ester group $\mathrm{C}=\mathrm{O}$ at $1769 \mathrm{~cm}^{-1}$. Carbon NMR analysis suggested the characteristic of $\mathrm{C}=\mathrm{O}$ ester at $169.8 \mathrm{ppm}$. Cross-coupling of methyl proton at $2.34 \mathrm{ppm}$ with $\mathrm{C}=\mathrm{O}$ ester supports the prediction for compound 4 . The structure of compound 3 and 4 are shown in Fig. 3. Thus, the ESI analysis of compound $2-5$ are determined by MS analysis data in Table 2.

Table 2. MS analysis for compound 2-6

\begin{tabular}{cccc}
\hline \multirow{2}{*}{ Comp. } & Experiment & \multicolumn{2}{c}{ Calculation } \\
\cline { 2 - 4 } & $\mathrm{m} / \mathrm{z}$ & $\mathrm{m} / \mathrm{z}$ & Formula \\
\hline 2 & 180.1153 & 180.1150 & $\mathrm{C}_{11} \mathrm{H}_{16} \mathrm{O}_{2}$ \\
3 & 178.1004 & 178.0994 & $\mathrm{C}_{11} \mathrm{H}_{14} \mathrm{O}_{2}$ \\
4 & 264.1367 & 264.1362 & $\mathrm{C}_{15} \mathrm{H}_{20} \mathrm{O}_{4}$ \\
5 & 222.1625 & 222.1620 & $\mathrm{C}_{14} \mathrm{H}_{22} \mathrm{O}_{2}$ \\
6 & 194.2773 & 194.2701 & $\mathrm{C}_{12} \mathrm{H}_{18} \mathrm{O}_{2}$ \\
\hline
\end{tabular}

The Friedel-Crafts reaction was also performed using $\mathrm{H}_{2} \mathrm{SO}_{4}$ without $\mathrm{CH}_{3} \mathrm{COOH}$ (Scheme 1 , route ii). A similar reaction was carried out. The crude reaction mixture was purified by $\mathrm{SiO}_{2}$ column chromatography and gave fraction four as a significant isolated product. Proton NMR analysis of the isolated products did not provide any characteristics of compounds 2-5. Further analysis using MS spectrometry detected molecular ion peak $\mathrm{m} / \mathrm{z}$ 194.2773 $\left(\mathrm{C}_{12} \mathrm{H}_{18} \mathrm{O}_{2}\right.$ required 194.2701), indicating compound 6 has four degrees of unsaturation arising from the benzene ring. From this experiment, the presence of acetic acid is essential for protecting the hydroxyl group, leading to the insertion of isopropyl into the benzene ring [13].

\subsection{Partition coefficient $(\log P)$ in $n$-octanol/water system}

Partition coefficient $(\log P)$ of compounds tabulated in Table 3. $\log P$ experiment using shake flask methods of compound 2 is 1.9 -fold higher than compound 1 , which expresses that the substitution of isopropyl increased the ability of the compound to penetrate the cell wall [20]. A $\log P$ value of 2 is identical to TQ suggesting that the compound's pharmacology effect is possibly similar to TQ [8]. The calculated $\log P$ data showed the same order as the experiment. It means that the partition ratio of the $n$ octanol/water system $(3: 7 \mathrm{v} / \mathrm{v})$ used in this experiment is appropriate [18].

Further, the Topological Surface Area (TPSA) analysis showed that compound 2 has a higher surface polarity than starting material 1 or TQ. It is predicted that hydroxyl groups are more potent in activating hydrogen bonding than carbonyl groups [21]. The hydroquinone headgroup reported has similar polarity with the quinone, but it can form stronger hydrogen bonding with water or $n$-octanol solution.

Table 3. Partition coefficient $(\log P)$ of the synthesized products

\begin{tabular}{cccc}
\hline \multirow{2}{*}{ Comp. } & \multicolumn{3}{c}{$\log P$} \\
\cline { 2 - 3 } & Experiment $^{\mathrm{a}}$ & TPSA $^{\mathrm{c}}$ \\
\hline $\mathrm{TQ}$ & 2.04 & 2.00 & 34.14 \\
1 & 1.02 & 1.22 & 40.46 \\
2 & 1.93 & 2.45 & 40.46 \\
\hline
\end{tabular}

a) Shake-flask method then chromatographed using HPLC

b) ALOGPS2.1 program

c) Predicted using molinspiration program

\section{Conclusion}

Friedel-Crafts reaction of 2,3dimethylhydroquinone (1) using mixed acid, $\mathrm{H}_{2} \mathrm{SO}_{4}$, and glacial acetic acid gave 5-isopropyl-2,3dimethylbenzene-1,4-diol (2) as a significant product. The formation of side products quinone derivatives compounds 3-5 was observed as minor products. Partition coefficient analysis in $n$-octanol/water systems showed the increasing solubility of compound 2, meaning the presence of isopropyl substitutions may influence the activity of the compound to penetrate the cell membrane. 


\section{Acknowledgment}

The author sends the utmost gratitude to Ritsumeikan University, Japan, for accessing NMR facilities.

\section{References}

[1] Bahareh Amin, Hossein Hosseinzadeh, Black cumin (Nigella sativa) and its active constituent, thymoquinone: an overview on the analgesic and anti-inflammatory effects, Planta Medica, 82, 01/02, (2016), 8-16

https://doi.org/10.1055/s-0035-1557838

[2] Mohammad Rashidmayvan, Majid Mohammadshahi, Seyed Saeed Seyedian, Mohammad Hossein Haghighizadeh, The effect of Nigella sativa oil on serum levels of inflammatory markers, liver enzymes, lipid profile, insulin and fasting blood sugar in patients with non-alcoholic fatty liver, Journal of Diabetes \& Metabolic Disorders, 18, 2, (2019), 453-459 https://doi.org/10.1007/s40200-019-00439-6

[3] Yasmina K. Mahmoud, Heba M. A. Abdelrazek, Cancer: Thymoquinone antioxidant/pro-oxidant effect as potential anticancer remedy, Biomedicine \& Pharmacotherapy, 115, (2019), 108783 https://doi.org/10.1016/j.biopha.2019.108783

[4] Md Asaduzzaman Khan, Mousumi Tania, Shangyi $\mathrm{Fu}$, Junjiang $\mathrm{Fu}$, Thymoquinone, as an anticancer molecule: from basic research to clinical investigation, Oncotarget, 8, 31, (2017), 51907 https://doi.org/10.18632/oncotarget.17206

[5] Khalid M. Alkharfy, Ajaz Ahmad, Rao M. A. Khan, Waleed M. Al-Shagha, Pharmacokinetic plasma behaviors of intravenous and oral bioavailability of thymoquinone in a rabbit model, European journal of drug metabolism and pharmacokinetics, 40, 3, (2015), 319-323

https://doi.org/10.1007/s13318-014-0207-8

[6] Chern Chiuh Woo, Alan Prem Kumar, Gautam Sethi, Kwong Huat Benny Tan, Thymoquinone: potential cure for inflammatory disorders and cancer, Biochemical Pharmacology, 83, 4, (2012), 443-451 https://doi.org/10.1016/j.bcp.2011.09.029

[7] Mujahid Yusufi, Sanjeev Banerjee, Momin Mohammad, Sandhya Khatal, K. Venkateswara Swamy, Ejazuddin M. Khan, Amro Aboukameel, Fazlul H Sarkar, Subhash Padhye, Synthesis, characterization and anti-tumor activity of novel thymoquinone analogs against pancreatic cancer, Bioorganic \& Medicinal Chemistry Letters, 23, 10, (2013), 3101-3104

https://doi.org/10.1016/j.bmcl.2013.03.003

[8] Ahmed H. Abdelazeem, Yasser M. A. Mohamed, Ahmed M. Gouda, Hany A. Omar, Majed M. Al Robaian, Novel thymohydroquinone derivatives as potential anticancer agents: design, synthesis, and biological screening, Australian Journal of Chemistry, 69, 11, (2016), 1277-1284 https://doi.org/10.1071/CH16102

[9] Yu N. Antonenko, A. V. Avetisyan, L. E. Bakeeva, B. V. Chernyak, V. A. Chertkov, L. V. Domnina, O. Yu Ivanova, D. S. Izyumov, L. S. Khailova, S. S. Klishin, Mitochondria-targeted plastoquinone derivatives as tools to interrupt execution of the aging program. 1. Cationic plastoquinone derivatives: synthesis and in vitro studies, Biochemistry (Moscow), 73, 12, (2008), 1273-1287

https://doi.org/10.1134/So006297908120018

[10] Novia Eka Setyatama, Siti Mariyah Ulfa, Hideki Okamoto, Synthesis and Activity Analysis of 3-(10Bromodecyl)-5-isopropyl-2-methyl-1, 4benzoquinone: In-silico Approach, Proceedings of the 1st International Conference in One Health (ICOH 2017), 2018 https://dx.doi.org/10.2991/icoh-17.2018.24

[11] Siti Mariyah Ulfa, Shoimatus Sholikhah, Edi Priyo Utomo, Synthesis of Thymoquinone derivatives and its activity analysis: In-silico approach, AIP Conference Proceedings, 2017

https://doi.org/10.1063/1.4978175

[12] Yusuke Myobatake, Kenji Takemoto, Shinji Kamisuki, Natsuki Inoue, Ayato Takasaki, Toshifumi Takeuchi, Yoshiyuki Mizushina, Fumio Sugawara, Cytotoxic alkylated hydroquinone, phenol, and cyclohexenone derivatives from Aspergillus violaceofuscus Gasperini, Journal of Natural Products, 77, 5, (2014), 1236-1240 https://doi.org/10.1021/np401017g

[13] George A. Olah, Stephen J. Kuhn, Sylvia H. Flood, Aromatic Substitution. X. 1 The $\mathrm{AlCl}_{3} \cdot \mathrm{CH}_{3} \mathrm{NO}_{2}-$ Catalyzed Benzylation of Benzene and nAlkylbenzenes with Benzyl Chloride in Nitromethane Solution, Journal of the American Chemical Society, 84, 9, (1962), 1688-1695 https://doi.org/10.1021/ja00868a039

[14] Cheryl S. Leung, Siegfried S. F. Leung, Julian TiradoRives, William L. Jorgensen, Methyl effects on protein-ligand binding, Journal of Medicinal Chemistry, 55, 9, (2012), 4489-4500 https://doi.org/10.1021/jm3003697

[15] Felix Ditzinger, Daniel J. Price, Alexandra-Roxana Ilie, Niklas J. Köhl, Sandra Jankovic, Georgia Tsakiridou, Simone Aleandri, Lida Kalantzi, René Holm, Anita Nair, Lipophilicity and hydrophobicity considerations in bio-enabling oral formulations approaches-a PEARRL review, Journal of Pharmacy and Pharmacology, 71, 4, (2019), 464-482 https://doi.org/10.1111/jphp.12984

[16] Stefan Paula, Josh Abell, Joel Deye, Christopher Elam, Michael Lape, Justin Purnell, Robert Ratliff, Kelly Sebastian, Jodie Zultowsky, Robert J. Kempton, Design, synthesis, and biological evaluation of hydroquinone derivatives as novel inhibitors of the sarco/endoplasmic reticulum calcium ATPase, Bioorganic \& Medicinal Chemistry, 17, 18, (2009), 6613-6619 https://doi.org/10.1016/j.bmc.2009.07.075

[17] Siti Mariyah Ulfa, Fath Dwisari, Ade Cintyia Sally, Mohammad Farid Rahman, Effect of methyl substituent on the solubility of 1,4-benzoquinone derivatives in n-octanol/water system, Jurnal Kimia Sains dan Aplikasi, 23, 5, (2020), 142-146 https://doi.org/10.14710/jksa.23.5.142-146

[18] Axel Andrés, Martí Rosés, Clara Ràfols, Elisabeth Bosch, Sonia Espinosa, Víctor Segarra, Josep M. Huerta, Setup and validation of shake-flask procedures for the determination of partition coefficients (log D) from low drug amounts, European Journal of Pharmaceutical Sciences, 76, (2015), 181-191 https://doi.org/10.1016/j.ejps.2015.05.008 
[19] Mohamed Elagawany, Lamees Hegazy, Feng Cao, Maureen J. Donlin, Nigam Rath, John Tavis, Bahaa Elgendy, Identification of 4-isopropylthiotropolone as a novel anti-microbial: regioselective synthesis, NMR characterization, and biological evaluation, RSC Advances, 8, 52, (2018), 29967-29975 https://doi.org/10.1039/C8RA06297H

[20] Barry S. Braun, Uli Benbow, Paul Lloyd-Williams, J. Malcolm Bruce, P. Leslie Dutton, Determination of partition coefficients of quinones by highperformance liquid chromatography, Methods in Enzymology, 125, (1986), 119-129 https://doi.org/10.1016/S0076-6879(86)25011-9

[21] Maximiliano Martínez-Cifuentes, Wilson Cardona, Claudio Saitz, Boris Weiss-López, Ramiro ArayaMaturana, A study about regioisomeric hydroquinones with multiple intramolecular hydrogen bonding, Molecules, 22, 4, (2017), 593 https://doi.org/10.3390/molecules22040593 